Volume 1 Issue 1, January-June 2020: pp.39-50.

Faculty of Law, Universitas Lampung, Bandar Lampung, Indonesia.

http://jurnal.fh.unila.ac.id/index.php/ip

P-ISSN: 2723-2638

E-ISSN: $2745-9314$

\title{
Gugatan Ganti Kerugian Dalam Tindak Pidana Untuk Mewujudkan Keadilan Bagi Korban
}

\section{Claim for Damages in Criminal Actions to Achieve Justice for Victims}

Gatra Yudha Pramana

dang.krui@gmail.com

Kejaksaan Negeri Lampung Utara

Submitted: Mar 10, 2020; Reviewed: Mar 26, 2020; Accepted: Apr 16, 2020

\begin{tabular}{|c|c|}
\hline Info Artikel & Abstrak \\
\hline $\begin{array}{l}\text { Kata Kunci: Ganti Rugi; Keadilan; } \\
\text { Korban. } \\
\text { Keywords: Compensation; Justice; } \\
\text { Victim. }\end{array}$ & $\begin{array}{l}\text { Penyelesaian perkara pidana, sistem peradilan } \\
\text { pidana lebih memperhatikan hak-hak terdakwa } \\
\text { oleh hukum, sementara hak korban untuk } \\
\text { mendapatkan keadilan berupa ganti kerugian } \\
\text { belum secara maksimal terwujud. Tulisan ini }\end{array}$ \\
\hline $\begin{array}{l}\text { DOI: } \\
\text { https://doi.org/10.25041/ip.v1i1.2066 }\end{array}$ & $\begin{array}{l}\text { bertujuan untuk melihat implementasi gugatan } \\
\text { ganti kerugian dalam tindak pidana. Penelitian } \\
\text { ini mengunakan metode yuridis normatif. Hasil } \\
\text { penelitian menunjukan bahwa kedudukan } \\
\text { korban dalam Sistem Peradilan Pidana, saat ini } \\
\text { belum sesuai dengan prosedur dalam } \\
\text { menggugat pelaku tindak pidana. Sehingga } \\
\text { untuk mengajukan tuntutan ganti kerugian, } \\
\text { pihak korban tindak pidana belum } \\
\text { mendapatkan kepastian hukum. } \\
\text { Abstract } \\
\text { jettlement of criminal cases, the criminal } \\
\text { of the accused by law, while the victim's right } \\
\text { to obtain justice in the form of compensation } \\
\text { has not been maximally realized. This paper } \\
\text { aims to see the implementation of the claim for } \\
\text { compensation in criminal offenses. This study } \\
\text { uses normative and empirical juridical }\end{array}$ \\
\hline
\end{tabular}


methods. The results showed that the position of the victim in the Criminal Justice System, both according to the Criminal Code (KUHP) and the Criminal Procedure Code (KUHAP) are currently not equivalent to the perpetrators of criminal acts. So to file a claim for compensation, the victim of a criminal offense has not received legal certainty. Even though the Criminal Procedure Code and the Criminal Code have given a little room for victims to get true justice as a result of acts or criminal acts committed by criminals.

\section{A. Pendahuluan}

Keadilan hukum bagi seluruh rakyat menjadi tugas negara yang dijalankan berdasarkan peraturan perundang-undangan. Keadilan merupakan salah satu tujuan hukum yang paling banyak dibicarakan sepanjang perjalanan filsafat hukum. Tujuan hukum bukan hanya keadilan, tetapi juga untuk kepastian hukum, dan kemanfaatan. ${ }^{1}$ Posisi sentral dalam sistem peradilan pidana apalagi korban adalah pihak yang mengalami tindak pidana dan kemungkinan besar mengalami kerugian dari tidak pidana yang terjadi. Upaya perlindungan korban melalui peradilan pidana selama ini belum terwujud atau terlaksana dengan baik. Oleh sebab itu maka ketentuan-ketentuan dalam undang-undang harus ditegakkan bagaimanapun caranya dan mest diperlakukan sebagai representasi dari nilai-nilai keadilan. ${ }^{2}$ Masalah kejahatan selalu difokuskan pada apa yang dapat dilakukan terhadap pelaku tindak pidana dan tidak memperhatikan apa yang dapat dilakukan untuk korban. ${ }^{3}$

Korban kejahatan adalah pihak yang mengalami kerugian dari perbuatan pidana, sudah seharunya mendapatkan perlindungan, namun seringkali dianak tirikan oleh berbagai aturan dengan alasan sudah diwakili oleh Negara melalui perangkat hukum yang ada. Korban kejahatan dapat memperoleh ganti kerugian berdasarkan putusan pengadilan. ${ }^{4}$ Dalam rangka menegakkan keadilan melalui supremasi hukum, semua pihak yang terkait dalam penegakan hukum harus mematuhi peraturan yang telah berlaku di negara Indonesia agar terciptanya keadilan untuk semua pihak sehingga tidak terciptanya ketidak harominisan dalam penegakan hukum. ${ }^{5}$ Untuk itu dalam membangun negara hukum yang berkeadilan bagi Indonesia adalah dengan mengacu pada amanah konstitusi. ${ }^{6}$

Indonesia adalah Negara hukum yang berupaya menyandingkan prinsip-prinsip negara hukum dengan prinsip-prinsip kedaulatan rakyat itu sendiri secara selaras dan saling melengkapi satu sama lain. ${ }^{7}$ Untuk itu sampai sekarang perlindugan korban kejahatan diposisikan hanya sebagai alat untuk mendukung pembuktian yang memaparkan informasi

\footnotetext{
${ }^{1}$ Mahir Amin, “Konsep Keadilan Dalam Perspektif Filsafat Hukum Islam.” Jurnal Hukum dan Perundangan Islam. Vol. 4. No. (2014). hlm.323.

${ }^{2}$ Moh khasan, "Prinsip-Prinsip Keadilan Hukum Dalam Asas Legalitas Hukum Pidana Islam.” Jurnal Rechtsvinding . Vol. 6. No. 1 (2017). hlm.23.

${ }^{3}$ Suzanalisa, "Rehabilitasi Dan Konsep Ganti Kerugian Bagi Korban Perkosaan.” Jurnal Lex Spesialis. No. 22 (2015).

${ }^{4}$ Rena Yuliana, "Mengkaji Kembali Posisi Korban Kejahatan Dalam Sistem Peradilan Pidana." Jurnal Mimbar Hukum. Vol. 28. No. 1. hlm.43.

5 Achmad Muchlis, "Penegakan Hukum Terhadap Tindak Pidana Korupsi Dengan Kerugian Negara Yang Kecil Dalam Mewujudkan Keadilan.” Jurnal Fiat Justisia. Vol. 10. Issue 2 (2016).hlm. 343.

${ }^{6}$ Umar Shollahudin, "Hukum dan Keadilan Masyarakat (Analisis Sosiologi Hukum terhadap Kasus Hukum Masyarakat Miskin "Asyani" di Kabupaten Situbondo). Jurnal Kajian Sosiologi Hukum. (2011).

${ }^{7}$ Shandi Patria Airlangga, "Hakikat Penguasa dalam Negara Hukum Demokratis", Jurnal Cepalo, 3 (1), (2019). hlm.4.
} 
yakni saksi, oleh karena itu kesempatan korban untuk mendapat kebebasan dalam memperjuangkan hak-haknya sangatlah sedikit. Mengenai penyelesaian perkara pidana, hakhak tersangka acapkali dijadikan prioritas oleh hukum, sementara hak-hak korban terkadang dilupakan. ${ }^{8}$ Namun, Kendala bagi hakim di pengadilan dalam putusan ganti rugi kepada korban oleh pelaku dalam kasus harta benda ini juga terjadi ketika pelaku dari segi ekonomi adalah menengah ke bawah dan terlebih tidak memiliki orang yang bisa memberikan jaminan. ${ }^{9}$

Hingga kini, yang menjadi landasan perlindungan hukum terhadap korban ialah UndangUndang Nomor 8 Tahun 1981 tentang Kitab Undang-Undang Hukum Acara Pidana (KUHAP) sebagai sumber hukum materiil. Dalam KUHAP, aturan yang ada kaitannya dengan tersangka atau terdakwa lebih banyak dibahas dibandingkan tentang korban. Status korban dalam KUHAP bisa dikatakan belum maksimal bila dilakukan perbandingan terhadap status pelaku kejahatan. Belum ada ketegasan yang tertera dalam KUHAP mengenai perumusan ketentuan yang secara riil untuk melindungi korban. Mengenai penjatuhan pidana, seharusnya terdapat konsiderasi tentang dampak dari tindak pidana bagi korban atau keluarganya. Selain itu, tak ada rumusan tentang tindak pidana restitusi (ganti rugi) dalam KUHAP yang sejatinya memiliki faedah yang besar untuk korban beserta keluarganya. Perumusan pasal-pasal dalam KUHAP kebanyakan berfokus pada perumusan tindak pidana, pertanggungjawaban dan ancaman pidana. ${ }^{10}$

Hal tersebut juga menjadi bagian dari doktrin hukum pidana yang berperan sebagai latar belakangnya. masalah hukum pidana mencakup tindakan yang tak diboleh dilakukan (kejahatan) dan memiliki aspek kesalahan (guilt), termasuk ancaman pidana (punishment). Kitab Undang-undang Hukum Pidana (KUHP) mengikuti aliran neo klasik di mana aliran tersebut memperbolehkan diberlakukannya situasi-situasi yang bisa memberikan keringanan untuk pihak yang melakukan tindak pindana yang berkaitan dengan fisik, lingkungan, dan mental. Berfokus dan meninjau pemaparan di atas, dapat ditarik kesimpulan bahwasanya fokus dari pengaturan KUHP adalah pelaku kejahatan, sementara itu hal-hal yang berkenaan dengan korban tidak begitu dipedulikan. Agar posisinya seimbang, semestinya KUHP menaruh perhatian pula terhadap korban sebagai pihak yang mengalami kerugian atau derita karena aksi pelaku kejahatan. ${ }^{11}$

Perhatian KUHAP terhadap korban kejahatan yaitu berkenaan dengan dipercepatnya serangkaian kegiatan dalam mendapatkan ganti kerugian yang dialami sebagai akibat dari tindakan tersangka melalui penggabungan perkara pidananya dan perkara gugatan ganti kerugian yang pada dasarnya ialah perkara perdata. ${ }^{12}$ Ganti rugi dalam ranah pidana diartikan suatu kewajiban yang dibebankan kepada orang yang telah bertindak melawan hukum dan menimbulkankerugian pada orang lain karena kesalahannya. ${ }^{13}$ Rumitnya masalah hukum sekarang ini pastinya memerlukan atensi khusus dari aparat penegak hukum, pemerintah, dan masyarakat dalam upaya ditegakkannya hukum dan penanggulangan pelbagai tindak pidana, termasuk merealisasikan keadilan dan kesejahteraan bagi masyarakat, khususnya bagi korban kejahatan. Perlindungan terhadap korban tidak hanya berbatas pada pemberian ganti

\footnotetext{
${ }^{8}$ Dikdik Arief, Urgensi Perlindungan Korban Kejahatan. Bandung: Rajawali Pers 2007, hlm. 25

9 Sherly Tricia Ningsih, "Pemberian Ganti Rugi oleh Pelaku kepada Korban Kejahatan Harta Benda menurut KUHAP." Jurnal Kriminologi Indonesia. Vol. 10. No. 2. hlm. 56.

${ }^{10}$ UU No. 8 Tahun 1981 tentang KUHAP

11 Angkasa. Kedudukan Korban dalam Sistem Peradilan Pidana, Disertasi, Semarang Universitas Diponegoro:. 2004, hlm.169-172.

${ }^{12}$ Leden Marpaung, Proses Tuntutan Ganti Kerugian Dan Rehabilitasi,: Jakarta: Rajawali Pers 2007, hlm.80

${ }^{13}$ Musnaini, "Ganti Rugi Bagi Korban Salah Tangkap Atau Salah Tahan Dalam Qanun Nomor 7 Tahun 2013 Tentang Hukum Acara Jinayah Ditinjau Menurut Hukum Islam.” Legitimasi: Jurnal Hukum Pidana dan Politik Hukum. Vol. 6.No. 2 (2017). hlm. 234.
} 
kerugian/restitusi namun juga pada pemulihan hak-hak anak untuk dapat tumbuh dan berkembang serta mendapatkan haknya dalam bidang pendidikan, sosial dan budaya. ${ }^{14}$

Berdasarkan fakta di lapangan, pihak yang menjadi korban tindak kejahatan nyatanya tak hanya mengalami kerugian secara materiil, namun juga kerugian immateriil yang ada hubungannya dengan kondisi psikologis korban. Pada hakekatnya, gugatan berhak diajukan oleh korban atas kerugian yang dialaminya karena kejahatan yang dilakukan pelaku tindak pidana. Mengingat gugatan ini begitu krusial dalam usaha merealisasikan keadilan bagi para korban, tak satu pun yang merefleksikan sensitivitas termasuk memunculkan putusan yang bermakna untuk dipulihkannya derita atau kerugian yang dirasakan korban.

Pemberian ganti rugi bagi korban menjadi salah satu manifestasi perhatian terhadap hakhak korban walaupun pada hakekatnya implementasi pemberian ganti rugi dari pelaku kepada korban dan atau keluarganya tidak dapat dengan mudah diterapkan untuk kejahatan pencurian dengan kekerasan. Seperti halnya pada Putusan Majelis Hakim PN Kota Agung Nomor 103/Pid.B/2018/PN Kot yang menyatakan terdakwa Samsudin alias Din Talo bin Zubaidi telah terbukti secara sah dan meyakinkan bersalah melakukan tindak pidana Pencurian Dengan Kekerasan Dalam Keadaan Memberatkan dan menjatuhkan pidana terhadap terdakwa oleh karena itu dengan pidana penjara selama 2 (dua) tahun 8 (delapan) bulan ${ }^{15}$. Berdasarkan latar belakang tersebut penting kiranya untuk dilakukan penelitian berkaitan dengan pelaksanaan gugatan ganti kerugian dalam tindak pidana, studi kasus ini dilakukan di Pengadilan Negeri Kota Agung.

Berdasarkan pada uraian-uraian di atas maka yang menjadi permasalahan dalam pembahasan ini adalah bagaimanakah implementasi ganti kerugian terhadap korban dalam tindak pidana yang ada di Pengadilan Negeri Kota Agung dan apa yang seharusnya hakim Pengadilan Negeri Kota Agung laksanakan dalam ganti kerugian terhadap korban dalam tindak pidana.

Pendekatan yang digunakan dalam pembahasan penelitian ini adalah metode yuridis empiris guna memperoleh hasil penelitian yang valid dan objektif. metode yuridis normatif juga digunakan dalam terkait hal-hal yang menyangkut ketentuan baik masalah peraturan perundangan, teori yang berkaitan, konsep-konsep serta peraturan lain yang masih berkaitan dengan pokok permasalahan.

\section{B. Pembahasan}

\section{Ganti Kerugian Korban dalam Tindak Pidana di Pengadilan Negeri Kota Agung}

Perkembangan hukum menjadi hal yang pasti seiring berkembangnya masyarakat demi mewujudkan keadilan bagi warga negara. Terbitnya Undang-Undang No. 31 Tahun 2014 tentang Perubahan Atas Undang-undang No. 13 Tahun 2006 tentang Perlindungan Saksi dan Korban telah menyebutkan apa yang menjadi hak Saksi dan Korban juga diatur tentang sebuah lembaga yang bertangungjawab untuk menangani pemberian perlindungan dan bantuan terhadap saksi dan korban. ${ }^{16}$ Hal ini menjelaskan bahwa memang derajat korban dalam sistem peradilan belum berada pada posisi yang setara dengan pelaku kejahatan bahkan beberapa aturan yang menjadi dasar pemulihan hak-hak korban kejatahan belum banyak dilaksanakan.

Permintaan penggabungan perkara gugatan ganti kerugian dalam perkara pidana merupakan menjadi hak korban sesuai dengan Pasal 98 ayat (1) KUHAP jauh sebelum Undang-Undang Nomor 31 Tahun 2014 tentang Perobahan Atas Undang-undang No, 13

\footnotetext{
${ }^{14}$ Nelsa Fadilla, "Upaya Perlindungan Hukum Terhadap Anak Sebagai Korban Tindak Pidana Perdagangan Orang." Jurnal Hukum Peradilan. Vol. 5. No. 2 (2016).hlm.193.

${ }^{15}$ Pengadilan Negeri Kota Agung

${ }^{16}$ Saristha Natalia Tuage, "Perlindungan Hukum Terhadap Saksi Dan Korban Oleh Lembaga Perlindungan Saksi Dan Korban (Lpsk).” Jurnal Lex Crimen. Vol. II.No. 2. (2013) hlm.56.
} 
Tahun 2006 ada juga sudah memberikan jaminan agar korban mendapatkan ganti kerugian dari tindak pidana yang dialaminya namun pada prakteknya jarang ditemui. Pasal 98 KUHAP ${ }^{17}$ sendiri menyatakan :

Ayat 1 "jika suatu perbuatan yang menjadi dasar dakwaan di dalam suatu pemeriksaan perkara pidana oleh pengadilan negeri menimbulkan kerugian bagi orang lain, maka hakim ketua sidang atas permintaan orang tersebut dapat menetapkan penggabungan perkara gugatan ganti kerugian kepada perkara pidana”.

Ayat 2" Permintaan sebagaiman dimaksud ayat (1) hanya dapat diajukan selambat-lambatnya sebelum penuntut umum mengajukan tuntutan pidana. Dalam hal penuntut umum tidak hadir, permintaan diajukan selambat-lambatnya sebelum hakim menjatuhkan putusan".

Hukum acara pidana tidak saja memperhatikan hak-hak dari pelaku tindak pidana (tersangka/terdakwa) saja, tetapi juga memperhatikan hak-hak dari si korban atau orang yang menderita kerugian yang di sebabkan oleh suatu tindak pidana. ${ }^{18}$

Kedudukan korban relatif kurang diperhatikan dalam system peradilan pidana di Indonesia karena ketentuan hukum masih bertumpu pada perlindungan bagi pelaku. ${ }^{19}$ Doktrin hukum tersebut tercermin dalam berbagai aturan hukum pidana yang ada. Hal tersebut berdampak pada tidak adanya perlindungan hukum yang pasti bagi korban dalam putusan hakim yang tidak memenuhi rasa keadilan bagi korban maupun masyarakat pada umumnya. Proses Penegakan hukum kemudian dengan didasari berbagai perangkat aturan perundangundangan hanya berputar perbuatan yang di lakukan pelaku saja, mulai dari pemenuhan rumusan pasal yang dilangar hingga kebenaran materiil terhadap peristiwa pidana yang terjadi menjadi jelas.

Tututan Jaksa Penuntut Umum dan Putusan hakim juga menitikberatkan pada penghukuman terhadap pelaku sebagai akibat dari perbuatanya tanpa mempertimbangkan aspek kerugian yang diderita oleh korban. Padahal Hakim dapat menggali nilai-nilai lain untuk dituangkan dalam putusan sesuai kewenangan hakim seperti yang telah diatur dalam Pasal 14 c KUHP. Dimana hakim memiliki kewenangan untuk menjatuhkan pidana bersyarat dengan syarat umum dan khusus dimana syarat khusus itu dapat memberikan kewajiban bagi terpidana untuk menganti kerugian yang dialami korban. Hakim juga dalam menyelesaiakn suatu perkara yang penting bukanlah hukumnya karena hakim dianggap tahu hukumnya (ius curla novit), melainkan mengetahui secara objektif fakta atau peristiwanya sebagai duduk perkara yang sebenarnya yang nantinya dijadikan dasar putusannya, bukan secara a priori langsung menemukan hukumnya tanpa perlu mengetahui terlebih dahulu duduk perkara yang sebenarnya. ${ }^{20}$

Berkaitan dengan pengajuan ganti kerugian yang dialami oleh korban. Yang harus menjadi perhatian adalah kerugian yang secara nyata ditimbulkan oleh tindak pidana itu sendiri, kerugian ditimbulkan sebagai akibat langsung dari tindak pidana tersebut, gugatan ganti kerugian ditujukan kepada pelaku tindak pidana, tuntutan ganti rugi yang diajukan digabungkan atau diperiksa dan diputus sekaligus bersamaan pada pemeriksaan dan putusan perkara pidana yang didakwakan kepada terdakwa dan dalam bentuk satu putusan. Prakteknya proses maupun prosedur dari substansi pengaturan penggabungan gugatan ganti kerugian dinilai memiliki, antara lain:

a. Sistem yang ada belum mendekati tujuan dari ganti kerugian;

\footnotetext{
${ }^{17}$ UU No. 8 Tahun 1981 tentang KUHAP

${ }^{18}$ Rianda Prima Putri, "Pemeriksaan Penggabungan Gugatan Ganti Kerugian Dalam Perkara Pidana Di Pengadilan Negeri Kelas 1b Bukittinggi." Jurnal Soematra Law Review. Vol. 1. No.1 (2018). hlm.177

${ }^{19}$ H. Parman Soeparman, Pengaturan Hukum Mengajukan Upaya Hukum Peninjauan Kembali dalam Perkara Pidana Bagi Korban Kejahatan, Bandung: Refika Aditama, 2007. hlm. 61

${ }^{20}$ Rizda Ardyati \& Evitha Astred Carollina. "Analisis Kewenangan Hakim Konstitusi Dalam Menafsirkan Peraturan Perundang-Undangan Berdasarkan Undang-Undang Nomor 48 Tahun 2008 Tentang Kekuasaan Kehakiman.” Jurnal Wacana Hukum. Vol. 25. No. 1 (2019). hlm.49.
} 
b. Hak menuntut ganti rugi hanya terbatas pada kerugian nyata/dampak langsung yang dirasakan oleh korban yang dirugikan;

c. Kerugian immateriil tidak dapat digabungkan dan harus mengajukan gugatan perdata tersendiri;

d. Mengaburkan tujuan awal untuk menyederhanakan proses dengan penggabungan perkara;

e. Terdapat hambatan dalam pelaksanaan pembayaran kerugian;

f. Jika korban tetap menuntut ganti kerugian sifatnya immateriil tidak memiliki hasil, putusan Hakim tetap tidak dapat diterima;

g. Majelis Hakim harus cermat, sebab selalu memisahkan antara kerugian materiil dengan kerugian immateriil, sehingga tidak efisien;

h. Gugatan ganti kerugian pada perkara pidana hanya bersifat assesor;

i. Korban menggantungkan diri kepada Jaksa Penuntut Umum untuk melakukan upaya hukum terhadap putusan.

Berkaitan dengan pelaksanaan gugatan ganti kerugian terebut, seperti halnya pada Putusan Majelis Hakim PN Kota Agung Nomor 103/Pid.B/2018/PN Kot diketahui kronologis pekara sebagai berikut : Dalam perkara ini, pada hari Kamis tanggal 19 Mei 2016 sekira pukul 15.00 WIB di jalan raya irigasi portal tulung indik, Pekon Tulung Asahan Kec. Semaka Kab. Tanggamus terjadi tindak pidana pencurian dengan kekerasan yang dilakukan oleh terdakwa Din Talo secara bersama-sama dengan saksi Sahbuddin Als Din Joy, saksi Sahbuddin Als Din Picung, Tri Handoko, Rudi Gareng, dan Joni Iskandar mengambil 1 unit sepeda motor Honda Supra Fit S warna Hitam oranye dengan Nomor Polisi BE 5010 WF adalah milik saksi Agus Setiawan yang jika dinilai dengan uang sebesar Rp. 6.000.000 yang menyebabkan saksi Agus juga mengalami luka dan trauma. Majelis hakim memutuskan terpenuhinya semua unsur yang didakwaan sebagaimana dirumuskan dalam dakwaan alternatif Jaksa Penuntut Umum, maka para terdakwa dinyatakan telah terbukti secara sah dan meyakinkan menurut hukum bersalah melakukan tindak pidana sebagaimana diatur dalam Pasal 365 ayat (2) ke- 2 KUHP sebagaimana dalam dakwaan Pertama Primair yang menyatakan terdakwa Samsudin alias Din Talo bin Zubaidi telah terbukti secara sah dan meyakinkan bersalah melakukan tindak pidana Pencurian Dengan Kekerasan Dalam Keadaan Memberatkan dan menjatuhkan pidana terhadap terdakwa oleh karena itu dengan pidana penjara selama 2 (dua) tahun 8 (delapan) bulan.

Pertimbangan Hakim yang meringankan dalam memutus perkara ini salah satunya adalah terdakwa telah berdamai dengan korban. Hakim menilai surat damai yang diajukan oleh Jaksa Penuntut Umum dalam persidangan menjadi dasar bahwa pelaku mau bertanggung jawab dan menganti kerugian yang dialami oleh korban.Namun kerugian yang dialami oleh korban berupa kehilangan sepeda motor senilai Rp. 6.000 .000 (enam juta rupiah) dan luka serta trauma yang dialami korban tidak dapat dipulihkan seperti yang korban inginkan karena tidak terdapat dalam amar putusan. Perkembangannya saat ini penegakan hukum berdasarkan pada asas kepastian hukum didasarkan pada peraturan masih menemui banyak kendala pada tataran pelaksanaan, terlebih pada kesenjangan yang cukup jauh antara peraturan perundangundangan dengan kenyataan yang dihadapi oleh pemerintah ${ }^{21}$

Hakim pada Pengadilan Negeri Kota Agung pada prateknya tidak pernah menerima adanya permohonan dari korban mengenai penggabungan gugatan ganti kerugian yang dialaminya, sedangkan korban tidak pernah mengenai jika dirinya memilik hak untuk mengajukan permohonan tersebut sebelum penuntut umum membacakan tuntutannya.

${ }^{21}$ Shidarta. 2013.Pendekatan Hukum Progresif Dalam Mencairkan Kebekuan Produk Legislasi, dalam Dekonstruksi dan Gerakan Pemikiran Hukum Progresif. Thafa Media.hlm27 
Ketidak tahuan korban mengenai haknya untuk dapat memperoleh ganti kerugian makin menegaskan bahwa aparatur penegak hukum yang mewakili diri korban atas nama Negara seolah meninggalkan dan mengambaikan apa yang menjadi hak dari korban. Ini menyebabkan penanganan perkara tindak pidana selama ini lebih mengedepankan kearah pemidanaan sebagai bentuk pelaksanaan penindakan. Hal ini sebenarnya lebih didasarkan kearah bagaimana seseorang dipidana, sehingga tidak diikuti oleh orang lain untuk melakukan hal tersebut (shock therapy). Fakta bahwa penanganan tindak pidana saat ini lebih berorientasi terhadap bagaimana memasukkan para pelaku sebanyak-banyaknya kedalam Lembaga Pemasyarakatan tidak bias dipungkiri, sedangkan kejahatan sendiri masih tetap merajalela. Sedangkan korban tindak pidana tetap belum menjadi objek yang menjadi perhatian dari para penegak hokum.

Proses peradilan dalam penggabungan gugatan ganti kerugian sejatinya tidak terlalu rumit dan sesuai dengan latar belakang munculnya penggabungan ini adalah untuk mengakomodir keadilan korban secara perdata tanpa harus memisahkannya dengan perkara pidananya pokoknya. Dalam hal ini hakim menunggu permohonan dari pihak yang mengalami atau menderita kerugian dari tindak pidana yang sedang disidangkan paling lama sebelum penuntut umum membacakan tuntutan pidananya. Untuk itu sudah sewajarnya Hakim memberikan pertimbangan tentang perkara pidana menimbulkan kerugian secara materiil bagi korban. Peran hakim menjadi sangat penting untuk mewujudkan kepastian hukum dan penegakan hukum, mencegah meluasnya tindak pidana. Jika korban menjadi pasif terhadap tindak pidana yang menimpa dirinya akan semakin banyak korban yang enggan untuk melaporkan tindak pidana yang dialaminya.

Hakim pada Pengadilan Negeri Kota Agung sekali lagi masih menjadi pelaksana undangundang. Sudah seharusnya hakim sebagai penegak hukum dan keadilan memberikan kepastian hukum bagi pelaku tindak pidana ataupun korban tindak pidana sehingga tercipta keadilan bagi keduanya. Seorang Hakim harus mampu dan aktif untuk menemukan hukum (Recht vinding) sebagai proses membuat hukum oleh hakim terhadap satu kejadian hukum yang konkrit yang menjadi dasar untuk mengambil keputusan.

Tidak adanya permohonan ganti kerugian yang diajukan oleh korban terkesan mengabaikan Pasal 98 KUHAP yang menyatakna bahwa penerapannya tidak diteparkan kepada korban tindak pidana. ${ }^{22}$ Padahal diketahui jika korban benar mengalami kerugian dari perbuatan pidana yang dilakukan. Hal ini menjadi penting untuk diperbincangkan dala Rancangan Undang-Undang (RUU) KUHP dan KUHAP mengenai kerugian baik secara maetiil dan immaterial yang dirasakan korban tindak pidana. Jika memang dalam implementasi dari Pasal 98 KUHAP sulit untuk dilaksankan, maka perlu ada solusi dan regulasi yang pasti mengenai hak korban untuk mendapatkan haknya mendapatkan ganti kerugian. Meskipun KUHAP sudah membatasi apa yang boleh dan tidak untuk dimintakan ganti kerugian, setidaknya aparat penegak hukum tetep dapat mengakomodir hak korban untuk mencari keadilan dengan memohonkan ganti kerugian atas apa yang dialaminya.

\section{Alasan Hakim Pengadilan Negeri Kota Agung tidak Melaksanakan Gugatan Ganti Kerugian dalam Tindak PidanaPencurian dengan Kekerasan}

Hingga kini, hukum pidana Indonesia masih belum menetapkan aturan mengenai kewajiban pelaku kehahatan untuk mengemban tanggung jawab atas tindakan yang telah dilakukan dan dampaknya bagi korban atau melakukan penggantian kerugian terhadap korban atau publik. Pelaku tindak pidana sekadar dijatuhi pidana penjara. Dengan memenjarakan

${ }^{22}$ Danil Rahmatsyah, et.al. "Implementasi Penerapan Ganti Kerugian Terhadap Korban Penganiayaan Di Banda Aceh." Kanun Jurnal Ilmu Hukum. Vol.18. No. 2 (2016). hlm.269. 
pelaku kejahatan memang akan menyebabkan minimnya kebebasan yang dimiliki pelaku, namun sejatinya hal tersebut juga mengakibatkan berkurangnya tanggung jawab pelaku pada korban.

Pada sistem hukum pidana Indonesia, usaha dalam memberikan perlindungan bagi korban kejahatan lewat lembaga restitusi dan kompensasi bisa ditemukan dalam KUHP, KUHAP, dalam Undang-undang Nomor 26 Tahun 2000 tentang Pengadilan Hak Asasi manusia, Undang-Undang Nomor 31 Tahun 2014 tentang Perobahan Atas Undang-undang No, 13 Tahun 2006, dan beberapa Undang-Undang khusus lainnya. Korban menurut Resolusi Majelis Umum PBB Nomor 40/34 Tahun 1985 meliputi orang-orang yang secara individu atau berkelompok, yang menderita kerugian sebagai dampak dari tindakan atau tidak berbuat yang tak mematuhi hukum pidana yang sah di sebuah negara, tak terkecuali aturan yang tidak memperbolehkan adanya tindakan yang berkaitan dengan menyalahgunakan wewenang.

Kemudian dijelaskan, terdapat pertimbangan bahwasanya seseorang bisa juga dikonsiderasi sebagai korban tanpa harus mengetahui apakah telah dilakukan penahanan, penuntutan, dan penjatuhan pidana terhadap pelaku kejahatan dan tanpa mempertimbangkan ikatan keluarga antara pelaku dan korban. Istilah korban juga meliputi kerabat atau pihakpihak yang korban tanggung termasuk yang mengalami kerugian sebab adanya upaya mereka dalam pencegahan terjadinya korban.

Hukum pidana positif baik materil maupun formil sudah memberikan aturan yang berkenaan dengan usaha dalam melindungi korban kejahatan lewat lembaga restitusi dan kompensasi. Antara lain tertera dalam ketentuan-ketentuan berikut, yakni perihal penjatuhan pidana bersyarat yang ditetapkan hakim. Sesuai dengan Pasal 14 c KUHP, hakim dapat menetapkan syarat tertentu/khusus untuk terpidana mengganti kerugian baik seluruhnya atau sebagian yang menjadi akibat dari tindak pidana yang diperbuatnya. Desti Jaksa Penuntut Umum Pengadilan Negeri Kota Agung, implementasi Pasal 14c KUHP memiliki kendala di antaranya:

1. Hakim tak bisa memberikan penetapan ganti rugi tersebut sebagai penalti yang sifatnya independen selain pidana pokok, alhasil sekadar sebagai persyaratan khusus bagi implementasi atau pelaksanaan penjatuhan pidana pokok terhadap terpidana

2. Diberikannya ganti rugi sebagai penetapan syarat khusus tersebut hanya bisa dilaksanakan bilamana hakim memutuskan penjatuhan pidana paling lama satu tahun atau pidana kurungan

3. Persyaratan khusus yang merupakan ganti rugi tersebut dan berdasarkan KUHP sifatnya ialah fakultatif, bukan imperatif.

Hakim Pengadilan Negeri Kota Agung memberikan penjelasan bahwa ada tiga hak hukum yang termuat dalam KUHAP yang bisa diterapkan korban kejahatan dalam tahapan peradilan pidana. Pertama, hak untuk melakukan kontrol terhadap penyidik dan penuntut umum, yakni hak untuk melakukan pengajuan ketidaksetujuan terhadap aksi diberhentikannya penyidikan dan/atau dihentikannya tuntutan dalam kapasitasnya sebagai pihak ketiga yang memiliki kepentingan. Hal tersebut tercantum dalam Pasal 77 jo 80 KUHAP). Kedua, hak korban kejahatan yang berkenaan dengan statusnya sebagai saksi, yakni hak untuk tidak lagi berpartisipasi memerankan peranannya sebagai saksi seperti yang tertera dalam 168 KUHAP dan hak bagi keluarga korban, dalam hal korban meninggal dunia, untuk memberi izin atau melarang polisi untuk mengotopsi. Hal tersebut tercantum dalam Pasal 134-136 KUHAP. Ketiga, hak untuk melakukan tuntutan ganti rugi terhadap kerugian yang dirasakan atas kejahatan sesuai dengan Pasal 98 hingga Pasal 101 KUHAP. Atensi KUHAP terhadap korban suatu kejahatan khususnya tidak pidana pencurian dengan kekerasan yaitu berupa dipercepatnya proses dalam pemulihan ganti kerugian yang dialami oleh korban sebagai 
dampak dari tindakan terdakwa melalui penggabungan perkara pidananya dan perkara gugatan ganti kerugian yang pada dasarnya dikategorikan sebagai perkara perdata.

Sistem ganti rugi dalam KUHAP cenderung condong pada sistem yang kedua, yakni pemberiannya direalisasikan lewat proses pidana. Hal tersebut bisa dilihat dalam ketentuan tentang digabungkannya perkara gugatan ganti kerugian dalam Pasal 98 ayat (1) KUHAP yang berbunyi, "Jika suatu perbuatan yang menjadi dasar dakwaan di dalam suatu pemeriksaan perkara pidana oleh pengadilan negeri menimbulkan kerugian bagi orang lain, maka hakim ketua sidang atas permintaan orang itu dapat menetapkan untuk menggabungkan perkara ganti kerugian kepada perkara pidana itu." Yang disebut "orang lain" dalam Pasal 98 ayat (1) merujuk pada pihak korban kejahatan, yakni aksi yang menyebabkan kerugian bagi orang tersebut. Kata "dapat" mempunyai makna bahwasanya hakim ketua sidang memiliki wewenang menyetujui atau menyatakan penolakan terhadap pengajuan mengenai penggabungan perkara ganti kerugian dan perkara pidananya. Hakim ketua sidang mempunyai wewenang dalam penentuan kebijakan berkaitan dengan permohonan digabungkannya perkara perdata yang ada sangkut pautnya dengan orang lain yang tak memiliki keterlibatan dalam tindak pidana yang didakwakan terhadap pelaku. Apabila hal tersebut terjadi, maka hakim ketua sidang berkemungkinan menyatakan penolakannya terhadap digabungkannya perkara gugatan ganti kerugian. Apabila dibebankan pula tanggung jawabnya terhadap pihak lain, maka hakim ketua sidang telah bertindak benar jika menyatakan ketidaksetujuannya mengenai digabungkannya gugatan ganti kerugian tersebut. Sebaliknya, apabila gugatan tanggung jawab hanya dibebankan pada terdakwa saja, maka tak ada dalih atau alasan bagi hakim ketua sidang untuk menyatakan penolakannya terkait dengan digabungkannya perkara tersebut. Pengajuan permohonan tentang digabungkannya perkara gugatan ganti kerugian hanya bisa dilakukan paling lambat sebelum tuntutan pidana diajukan penuntut umum, atau apabila kehadiran penuntut umum tak bisa dipenuhi, maka pengajuan permintaan tersebut paling lambat dilakukan sebelum hakim melakukan penjatuhan putusan. Namun pengajuan permohonan seperti yang dimaksud tidak pernah dilakukan oleh para korban tindak pidana yang ada di wilayah hukum Pengadilan Negeri Kota Agung.

Putusan digabungkannya perkara memuat tentang perkara perdata dan pidananya. Korelasi antara perdata dan pidana dicantumkan pada Pasal 99 ayat (3) KUHAP. Mengenai Putusan ganti kerugian dengan sendirinya berkekuatan hukum tetap jika terhadap putusan pidananya juga mendapat kekuatan hukum tetap. ${ }^{23}$ Hal yang dirumuskan Pasal 99 ayat (3) KUHAP ini termasuk dampak yang realistis sebab tuntutan ganti kerugian mengikuti perkara pidana karena tuntutan perdata tersebut sebagai risiko dari pidana yang terjadi. Selain dari Pasal 99 ayat (3) KUHAP, Pasal 100 KUHAP lebih gamblang dalam menunjukkan korelasi antara putusan perdata dan putusan pidana, yang perumusannya yaitu:

(1) Apabila terjadi penggabungan antara perkara perdata dan perkara pidana, maka penggabungan itu dengan sendirinya berlangsung dalam pemeriksaan tingkat banding

(2) Apabila terhadap suatu perkara pidana tidak diajukan permintaan banding, maka permintaan banding mengenai putusan ganti rugi tidak diperkenankan.

Namun menurut Heni Siswanto Dosen Fakultas Hukum Universitas Lampung prakteknya gugatan kerugian yang diimplementasikan lewat mekanisme digabungkannya perkara pidana dan perdata, menghadapi hambatan, yaitu:

1. Tanggung jawab mengenai penggantian ganti rugi sifatnya ialah individual. Dengan kata lain, hal tersebut hanya dibebankan pada pihak yang tergugat tanpa melibatkan orang lain. Akibatnya, mustahil untuk menjamin korban dalam kaitannya dengan

${ }^{23}$ Ihwanul Muttaqin, "Hak Korban Atas Kerugian Dalam Perkara Pidana..” Jurnal Ilmu Hukum: Justice Pro. Vol. 4.No. 2 (2017).Hlm. 97. 
diimplementasikannya putusan ganti rugi sebab si pelaku tak mampu memenuhi kewajibannya.

2. Diperlukan adanya aksi aktif korban kejahatan, yakni pengajuan permohonan harus dilakukan terlebih dahulu sebelum tuntutan diajukan oleh jaksa, sementara itu kebanyakan korban umumnya tidak tahu tentang prosedur hukum yang berkaitan dengan ganti rugi

3. Dalam kegiatan pemeriksaan, terutama yang dilaksanakan dengan acara cepat dan hanya satu kali persidangan serta tak dibutuhkannya kegiatan memeriksa saksi dari pihak korban kejahatan, biasanya korban kejahatan tak diinformasikan mengenai jadwal persidangan, oleh karenanya korban kehilangan peluang untuk pengajuan gugatan ganti kerugian

4. Perkara gugatan ganti rugi berstatus tambahan (accesoir), yang tak terlepas dari perkara pokok (perkara pidananya), jadi apabila perkara pidananya sudah berkekuatan hukum tetap, berarti pengajuan upaya hukum tidak bisa dilakukan oleh penggugat.

Jaksa Penuntut Umum Pengadilan Negeri Kota Agung memberikan penjelasan bahwa adanya saksi dan/atau korban tersebut begitu krusial sebab acapkali aparat penegak hukum menghadapi kendala dalam pencarian kejelasan mengenai kejahatan yang dilakukan pelaku namun saksi dan/atau korban tak bisa hadir. Tak bisa hadirnya saksi dan/atau korban sebagai tanggapan dari apa yang diminta aparat penegak hukum acapkali terjadi karena korban dan/saksi diancam secara psikis atau fisik oleh pihak tertentu. Oleh karena itu, diperlukan adanya perlindungan yang ditujukan pada saksi dan/atau korban dalam tiap-tiap rangkaian tahapan peradilan. Perlindungan tersebut tak hanya berkaitan dengan pemberian proteksi dari bahaya yang sifatnya fisik atau psikis, namun juga meliputi dipenuhinya hak-hak saksi dan/atau korban dengan menyeluruh.

Sesuai dengan apa yang dipaparkan oleh narasumber, bisa dicermati bahwasanya diberikannya dan diwujudkannya hak-hak saksi dan/atau korban ini supaya dilandaskan asas penghargaan atas harkat martabat manusia, keamanan, adil, tak adanya diskriminasi, dan kepastian hukum serta pelaksanaannya dilakukan oleh lembaga independen yang memiliki kewajiban dan wewenang dalam penanganan mengenai diberikannya perlindungan beserta asistensi bagi saksi dan korban, yang dalam melaksanakan tugas dan wewenangnya supaya jauy dari kata dependen tanpa intervensi dari pihak manapun. Dengan demikian, saksi dan korban bisa menyampaikan keterangan dengan gamblang atau jelas, rinci tanpa mendapat tekanan dari pihak luar atau pihak yang memiliki kepentingan.

\section{Kesimpulan}

1. Gugatan ganti kerugian bagi korban tindak pidana khususnya pencurian dengan kekerasan yang ada pada wilayah hukum Pengadilan Negeri Kota Agung belum terimplementasi dengan baik. Hal ini dikarenakan tidak adanya upaya baik dari Jaksa Penuntut Umum maupun Hakim untuk memberitahukan apa yang menjadi hak korban sesuai dengan amanat Pasal 98 KUHAP. Sehingga jika korban ingin mengajukan tuntutan ganti kerugian, hanya dapat dilakuan secara kekeluargaan dengan pelaku kejahatan dengan bentuk surat perdamaian, namun sejatinya hal tersebut tidak memberikan rasa keadilan bagi korban.

2. Tidak diterapkannya penggabungan gugatan ganti kerugian oleh Hakim Pengadilan Negeri Kota Agung dikarenakan tidak pernah ada permohonan dari korban untuk meminta ganti kerugian. Selain itu, kurangnya pengetahuan dari korban mengenai hakhaknya justru membuat banyak korban tindak pidana menjadi pasif. Sehingga penyelesaian perkaranya hanya diserahkan sepenuhnya kepada Jaksa Penuntut Umum. Selain itu, hakim memutus perkara tanpa mempertimbangkan hak dan kerugian yang diderita oleh korban. 


\section{Daftar Pustaka}

A. Buku

Angkasa. Kedudukan Korban dalam Sistem Peradilan Pidana, Disertasi, Universitas Diponegoro: Semarang. 2004.

Andi Abdurrahman Nawawi, Tinjauan Umum Mengenai Gugatan Perdata, PT. Bina Cipta: Jakarta, 2000.

Andi Hamzah. Hukum Acara Pidana Indonesia, Sinar Grafika: Jakarta, 2005.

Dikdik Arief, Urgensi Perlindungan Korban Kejahatan. Rajawali Pers: Bandung. 2007.

Moeljatno. Asas-Asas Hukum Pidana, Rineka Cipta, Jakarta, 2013.

Rena Yulia, Viktimologi Perlindungan Hukum Terhadap Korban Kejahatan.Graha Ilmu: Yogyakarta, 2010.

Leden Marpaung, Proses Tuntutan Ganti Kerugian Dan Rehabilitasi. Rajawali Pers: Jakarta. 2007.

Wahyu Afandi. Ganti Rugi Dalam Perkara Pidana Setelah KUHAP, Sinar Harapan: Jakarta, 2012.

Rianda Prima Putri, "Pemeriksaan Penggabungan Gugatan Ganti Kerugian Dalam Perkara Pidana Di Pengadilan Negeri Kelas 1b Bukittinggi", SOUMATERA LAW REVIEW, Vol 1 No 1, (2018), doi: 10.22216/soumlaw.v1i1.3348.

B. Jurnal

Airlangga, S. P. "Hakikat Penguasa dalam Negara Hukum Demokratisi." Jurnal Cepalo, 3 (1), 4, $2019 . \quad$ https://jurnal.fh.unila.ac.id/index.php/cepalo/article/view/1783/1487 https://doi.org/10.25041/cepalo.v3no1.1783.

Amin, M. "Konsep Keadilan Dalam Perspektif Filsafat Hukum Islam." Jurnal Hukum dan

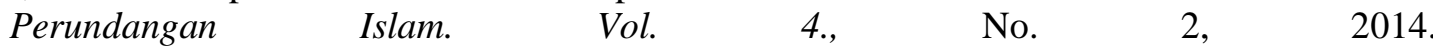
http://jurnalfsh.uinsby.ac.id/index.php/aldaulah/article/view/60/45, https://doi.org/10.15642/ad.2014.4.02.322-343.

Carollina, R. A. "Analisis Kewenangan Hakim Konstitusi Dalam Menafsirkan Peraturan Perundang-Undangan Berdasarkan Undang-Undang Nomor 48 Tahun 2008 Tentang Kekuasaan Kehakiman." Jurnal Wacana Hukum. Vol. 25. No. 1, 2019: 49. http://ejurnal.unisri.ac.id/index.php/Wacana/article/view/2948/pdf. http://dx.doi.org/10.33061/1.jwh.2019.25.1.2948.

Danil Rahmatsyah, e. "Implementasi Penerapan Ganti Kerugian Terhadap Korban Penganiayaan Di Banda Aceh." Kanun Jurnal Ilmu Hukum. Vol.18. No. 2,.2016: 269. http://www.jurnal.unsyiah.ac.id/kanun/article/view/5910/4901.

Dikdik Arief, Urgensi Perlindungan Korban Kejahatan. Rajawali Pers: Bandung. 2007.

Fadilla, N. "Upaya Perlindungan Hukum Terhadap Anak Sebagai Korban Tindak Pidana Perdagangan Orang." Jurnal Hukum Peradilan. Vol. 5. No. 2, 2016: 193. http://114.129.22.229:4070/index.php/jurnalhukumperadilan/article/view/36/46. http://dx.doi.org/10.25216/JHP.5.2.2016.181-194.

Moh khasan, "Prinsip-Prinsip Keadilan Hukum Dalam Asas Legalitas Hukum Pidana Islam." $\begin{array}{llllllll}\text { Jurnal Rechtsvinding. } & \text { Vol. } & 6 . & \text { No. } & 1\end{array}$ https://rechtsvinding.bphn.go.id/ejournal/index.php/jrv/article/view/133/133.

Muchlis, A. "Penegakan Hukum Terhadap Tindak Pidana Korupsi Dengan Kerugian Negara Yang Kecil Dalam Mewujudkan Keadilan." Jurnal Fiat Justisia. Vol. 10. Issue 2, 2016: 343. https://jurnal.fh.unila.ac.id/index.php/fiat/article/view/652/640. https://doi.org/10.25041/fiatjustisia.v10no2.652

Musnaini. "Ganti Rugi Bagi Korban Salah Tangkap Atau Salah Tahan Dalam Qanun Nomor 7 Tahun 2013 Tentang Hukum Acara Jinayah Ditinjau Menurut Hukum Islam." Legitimasi: Jurnal Hukum Pidana dan Politik Hukum. Vol. 6.No. 2, 2017: 243. https://jurnal.arraniry.ac.id/index.php/legitimasi/article/view/3957/2576.

http://dx.doi.org/10.22373/legitimasi.v6i2.3957 
Muttaqin, I. "Hak Korban Atas Kerugian Dalam Perkara Pidana." Jurnal Ilmu Hukum: Justice Pro. Vol. 4.No. 2, 2017: 97. http://www.jurnal.unsyiah.ac.id/kanun/article/view/5910/4901.

Ningsih, S. T. "Pemberian Ganti Rugi oleh Pelaku kepada Korban Kejahatan Harta Benda menurut KUHAP." Jurnal Kriminologi Indonesia. Vol. 10. No. 2, 2014: 49-58. http://journal.ui.ac.id/index.php/jki/article/viewFile/7559/3835.

Putri, R. P. "Pemeriksaan Penggabungan Gugatan Ganti Kerugian Dalam Perkara Pidana Di Pengadilan Negeri Kelas 1b Bukittinggi." Jurnal Soematra Law Review. Vol. 1. No.1, 2018: 177. https://www.researchgate.net/journal/2620-5904_Soumatera_Law_Review.

Rianda Prima Putri, "Pemeriksaan Penggabungan Gugatan Ganti Kerugian Dalam Perkara Pidana Di Pengadilan Negeri Kelas 1b Bukittinggi", SOUMATERA LAW REVIEW, Vol 1 No 1, (2018), doi: 10.22216/soumlaw.v1i1.3348.

Shollahudin, U. "Hukum dan Keadilan Masyarakat (Analisis Sosiologi Hukum terhadap Kasus Hukum Masyarakat Miskin "Asyani” di Kabupaten Situbondo)." Jurnal Kajian Sosiologi Hukum, Vol. 9, No. 1, 2016. https://journal.trunojoyo.ac.id/dimensi/article/view/3736/2737.

Suzanalisa. "Rehabilitasi Dan Konsep Ganti Kerugian Bagi Korban Perkosaan." Jurnal Lex $\begin{array}{llll}\text { Spesialis. } & \text { No. } & 2013 .\end{array}$ http://jih.unbari.ac.id/index.php/LEX_SPECIALIST/article/view/15/14.

Tuage, S. N. "Perlindungan Hukum Terhadap Saksi Dan Korban Oleh Lembaga Perlindungan Saksi Dan Korban (Lpsk)." Jurnal Lex Crimen. Vol. II.No. 2, 2013: 56. https://ejournal.unsrat.ac.id/index.php/lexcrimen/article/view/1541/1236..

Yuliana, R. "Mengkaji Kembali Posisi Korban Kejahatan Dalam Sistem Peradilan Pidana." Jurnal Mimbar Hukum. Vol. 28. No. 1., $2016: 43$. https://jurnal.ugm.ac.id/jmh/article/view/15858/10467.

C. Undang-undang

Undang-Undang Nomor 1 Tahun 1946 tentang Peraturan Hukum Pidana (Kitab Undang-Undang Hukum Pidana).

Undang-Undang Nomor 8 Tahun 1981 tentang Hukum Acara Pidana (Kitab Undang-Undang Hukum Acara Pidana).

Undang Undang Nomor 31 Tahun 2014 tentang Perobahan Atas UU No, 13 Tahun 2006 tentang Perlindungan Saksi dan Korban.

Peraturan Pemerintah Nomor 3 Tahun 2002 tentang Kompensasi, Restitusi, Dan Rehabilitasi Terhadap Korban Pelanggaran Hak Asasi Manusia. 